rent its gioruiation and tilus eut short tho aguo paroxysnis. Cares hayo been reported" by Mya, Thnyer, lioinet, Thintignan, Huuidieston, of Now York, and Mühll, of Baslo, and othen. If methyiene biue stains tire partisite or its nueleus, this blue, conmingling with the red of the bloot, wonli jroduco tio (to tiro paraito) disastrous vielet or purpio.

l'ossibly tivo (hitherto enigmaticai) curative action of suiphato of quinino may bo duo to its remarkabio fuoreacence. Iu solution it listensifies the violet, and oven renders tho uitra-violet rays of the spectrum perceptiblo to lutenan vision.

of the ferv vegetable produets having this quality of fluerescence, ancatier ono is escuilin, tho bitter prineipio of tho horso. eliestuat tree bark (Heulus hippocastanum). But this also has been suecesefully usei ns nul antiperiodie fer intermittent fover." Do theeo fllorescont substnuces act by intensitying vieiet rays in the bieed ?

If tho etiology now given bo correct, treatment is seil-ovinient, viz., kecin uniariai paticuts in tho dark, or in roomss witi purpio or indigo wiudewa, and ciothe thom witi garnents impenetrablo to light; in the tropics, with wisito elotiing linad with purpio or biaek, Givo drugg that ciarkes tio biood or rendor it vioiet, or lesaess its transiucones.

\title{
Brotolooraplly.
}

1. I'hliadel phla Nedical Journal, Auguat 23, 1827. Tho Banliarlan, Oclober, 1207, Pp. 8x-2ss.

2. Qualtefoges, The Iumeu speclet, p, 221 .

3. Santon. Tropleal Disences. Introducllon, $\mathrm{p} / \mathrm{x}$.

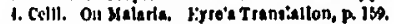

s. llioud, I'reclice of Nedictne, rol. I. p. 258.

6. Filisl. Juld., Iblad edilton, a 857 .

7. Vortsce. On Yoren, Arat Amertcan edtuon, p. 114.

8. Filis. Traclice of Mallelne, p. 865.

9. Welsh. Inomls and Thompeon, System of HodleJne, vol, I. p. 81.

10. Halls. Cluclunall Lancel and Obeerter, Horembar 18, J882, 1p. 179-189.

11. Gorton. Iandon Melleal Press and Clrculay, val. xxa. p. 800 .

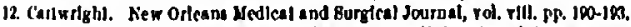

13. Frguson. Traneacllous of the nosal soclely of Ldinbirgh, vol. ly, pp, zi-290.

11. G:ler, Allbull, 8jalem of Nediclne, rol. \$1. p. 723.

15. Heleh. Joomls and Thampen, rol. I. p. 81 .

16. Ilarringlow and Leeming. Amerlcen Journat ol Pbjufology, rol. III. No. J, pp. 2-18.

17. Sajous' A anusl, 1893, vol. I. pp. 77-79.

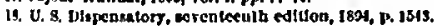

18. Jackion. Foren of Jamalca, Pp. B. 65. 185.

\section{ANGINA PEOTORIS.}

BY BevgRi,ey Rodingon, M.D., or MEF roax.

Axuisa Pectonts, in its typienl ferm, is in my oxperieneo a very rare tisease. Pseudo-angina, or what rezembies it at times, eardiao asthina, is not infrequont. Aithough angina petoris is deseribed among the ucuroses of tho heart by authors, thle vlew In my judguent 
is frequently erroneous. In the grent majority of iustauees where angiun is present thoro oxist nlso organio changes of the coronary eirenlatien, of the enrdine museular fibres, or a leslen oi the nertle orifices.

I should bo lonth to admit, oxeept in a vory oxceptional way, the existence of true augina purely of nenrotle origin. On the ether hanul, psende-nugiun is very frequently of this provennuce, aceompanled by symptoms of thatulent dyspepsia. It nust bo understood, howover, that there aro enses on the border-Jino in which, during life, wo havo grent difienlty in pronoumeing $n s$ to what syumptoms are of nerveus origin nud what nre clenrly due to organic chnuges of tho lienrt or arteries.

In many such instances, unfortunntely, oven if death occurs, wo are not nlways able to obtain verificatien of clibienl faets by the results of all autopsy. IIence, eertaln theories aro brought to the front whind linvo no bagis in actunl, rolinblo observatlons from the dead-house.

Ono stalomeit ls certainly true of anglun, vlz.: that it lins usually comneeted with lt nu clement of spasm or sudden Intracardiae pressure which ocparaics it notably from conditions whieh, in many ways, nre simllar, aud yet from this atand-point differ manifestly in a greater or lexs degrce. Of the truth of this stntement wo shall bo eenvineed later.

In generul, It may be stated that pain, properly spenking, docs not eliarneterizo organlo discaso of the heart as wo commenly ineet it. Of courso, thore may be moro or less prreeordial nuxiety or eppressien, or there may be pain in the vleinity whleh ls of stemaelal or hopatio origin; but aeute eardine pain ls very mre. lior thls reasen it lias hecemo almest mu nxieml for elinieians to my when neuto enrliae pain is complained of, it is moro thrn likely ne organie disense of the henrt is present. l'erhap!s this aflinuntion is too positivo or dogmatie, sluce I anl conflident functional distress may oeeur whieh lo dependent ujon obvions tissue clinnges.

In true angina the pain is very chamcteristic, nal as I havo sail, ordinarily menus organic clinuges of tho henrt strueturo. First of all, the pain of angima is marked by its great intenslty. In ne other diseuse, perlıajs, is this so truc. When the nnginoid nttnek occurs, if the patient is walking or exercising in any way, be stops immediately and lolds himself as quiet ns possible, only taking hold almost Involun. tarily at times, se grent lo lis distress, of tho nenrest objeet which will givo him support. Otherwise, ho may mercly stnid rigidly, having como to $\mathrm{n}$ short stop, with his arms lying unconeclously by lis side, or elso ello linul ls pressed firmly in the precerdial regien, ns if to nenelionto in a mensure the suljoective ngouly by so doing. During tho attnek the peetornl and other museles of respiration seareely movo, and, indeed, brentling comes almost to $n$ stand-still for a while. In this wo pereeive at once the great dissinilarity with au nttack of enrillne 
natlımn, in which tho offorts to brentho aro so foreiblo nul striking. Ainl yot there aro uwmerous instnnces in which tho enrdino asthastio fentums are most notable nud where tho "angina sine dolore" of (inirdoer is nlso presont,' ns Osler states, aftor a mastorly sunumnry of the differentinl dingnosis af theso two states, "when wo recall to nimil the fentures of the attnek in enrriae asthrun nud in cortain nuginal scizures, tho similarity of the condition, as IJuclinrl remarks, to an uente colphysens, tho viows of Von Baseh" appenr to possess at lenst a reasounhlo probabllity" (p. 85).

Tho locenlity of tho palo in nuginn is not always tho same. Fro. quently it is loented over tlio precerclial region. At tines, howover, it may be sitınted lu tho upper portion of tho ehest, or ngain, but in rela. tively fow lugtances, it nany stretcli liko n heavy lonr across the xiphoill cartilnge nnd the adjncent sl ruelures. Unilor these cirennsiances the pain miny ralinto directly through the chest null bo felt oven in tho hack. Tho pain has been likoned to a henyy weight or ernshing pressure, as though tho thorneio pariotes must nlmost meet. Tho pail is nlso snill to resemble that of somo terrible grijing, as thongh tho henrt wero firmily held in the eliteh of some terrible monster. All these sensations, numl numerous otliers, linve licen deseribed and ilwalt "jou by writere, who doubtless have iseal thelr imngination at times to silpply tho veseriptivo porrers of tho patient. Sufiles it to nild that the pain is of n frightful sert nnil quite unlike any other wo aro fnulliar witl. Often the radintion of the pain lo townal tho left arm, and in that case is usunlly enrried tlireugh the forearm nlao nud to tho fingere. Tho ring antl littlo fingers are snhl to bo usunlly nfiected. Very rarely tho palı cxtemls to the right nran. When it does it rallates likewiso ln ono or bi: hor direelion mentioned.

Aconling to Jrondbent, tho paln of angina ofton originates in tho left wrist, and from thero travels npwanl throigh tho loft arm and Inward tho ehest-or ngaln, as Osler states, although originating li tho chest," " was felt very covorely about both wrists." This mist bo an extremely rare oxpression of the paln. I liavo novor met it, nor ilo I fincl it mentlonel by others. It is elenr that tho relations of lorachial symptoins' (ncuralgin) to anginn pectoris are various. Sonetimes, tiongh in frequently, thero nro no palns in tho arms, oven in quito sovero at tncks of anglua. Again, tho brnelial symptoms aro very pronluont, legiu tho attack of angina, anil lnst longer than it does. Tho fact is, howover, that the deserlptlon of paln nal its radiation, especinlly where it has the remarkalble intensity of that belonging peeuliarly to

1 Oster. Anging Pecloris and Alllod Bitater, p. 82.

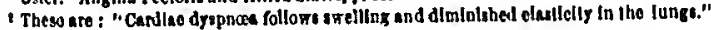

"Anglina Pechotil and Allted scutes." p. 12

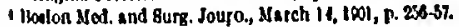


nnginn, must bo somowhat inaccurats nt times. In any ovent, it couid only bo ubenined after the attack has prezed, and I am inclined to hellovo that only exceptionally tho potlent eoulil givo nny graphio and trutheful ileseription of it. What is literaliy trus is that tho jatlent has tho Impression vivilly morked of Impeniliug dissolution, anil it is this senso, together with the charaeler, sitc, nnd evillent intensity of tho pain, whlch are almost pathognomonio of nugiaa.

I know of fow thlugs moro rounarknblo in deseriptivo ineilieino than tho necount given in the lifo of Divight I. Afooty by his son, of tho anginoid attack ncar tho closo of the lifo of tho great ovnngelist. In tlis cesso thoro was no torror or mentnl listrest; ns I bellovo, beenuss his foith nunl works fixed lini, as it were, on a roek. But ln very inany Instauces thore is inguestionably great terrer and montol distress. This is pietured often in tho eountenance which has that gray, ghastly, Iraw" look whjech onco seent lenves an indeliblo impresion upon tho observers who maj ho near. Tho different radiatiens of tho pain In angina nre, no doulit, rensonably oxpininel by tho position of tho cardinc ploxus. The slto of this plexus near the hearl would servo to strengthen this viow. In aldition, wo haro lis divisions anil communicentions which appear to justify this interpretation.

According to ono cminent obscrvor, the paln origluntes probably in tho centrul wervous syston. Thls writer also oxplalns its rallintion and oxtcusion by affirming that it procecels from the spinal corl. One thlog ls pretty certain, if wo may julgo by tho fow thorough observations we have recorded of theso enses, and it is that thoro is no presulre outsillo of the henrt on tho ploxus trom nny form of aneurien or other kind of tumor. W'blio tho heart may or may not be enlargel necoriling to eireunistnuces, this eulargement, even thengh present, dnes not explain mutioually tho mginoil symptons.

Cardino lyjportrophy nud enrdinc dilntation tro very frequently met with, anıl yet in tho vast nanjority of theso casts thero aro no anginoid symptons properly spenking. Lenving asils these instances, there are a for where the licart lo secmingly of normal szzo and volume, and wo must, thorofero, seek all oxplauation of anginail pains in some other direction. Liven in neuto eardiao dilatation, no lntenso pain to telt, nud yet wo alould havo in just surh crses pressuro on or distention of nor vous fibres undor tho ondocardiun. Morcover, this pressinro or distontion must bo very much grentor in patlents thus affected thinn in those euffering whel angina where no slmilar contition oxiste. During tho nttnek the patient is usuaily very palo, and tho palior has a certain gray, ashy huo which is indicativo of tho serious condition which ocensions It. 'Together with this pallor there is oxtrone weakness, and a faint fooling, whloh connot bo resisted, ovor whelms tho ludividunl who is ntlncked. 't'ho pulse shows by its chamcter, oftentimes upon whas 
this wenkness in part depends. It is frequently smali, teebie, irreguins, as tiougin the pooriy acting heart could not enil the blood to the extremitles. Again, singular to say, it is nlmost unehanged, at least $z 0$ far as we ean appreciato by our tnetiio selisations. In tino former instnneo, it is probnhio that thero ls present a spasmodio contraction of tive periplierai arterles; in the inttor, wo nulist nesume that no suel spasm oxists, or, Indeed, that arterial changes nro so ndvanced that 110 unrked lnpression is mado upon their contraetibiiity oven by tho most intenso pain nnd distusbruco of the central orgnn of cirenintion.

Frequentiy en ettack of anginn tormioetes by $n$ sutiten oxplosion of gns from tho stonneh. ILeuco, it is often stated ond faniliariy aecepted that fintuiont dyspepsin is an inmmediato and efficient caueo of a true attnek of aagina. In my experionee this is ecarcoiy truo, and I nm moro inclined to tho boiiot tiot lt is eqpeciaiiy In cases of peudo.onginn tint wo sileuid expect to finl synptomis of slomachal weakness or intolernuco. Whito adtnitting this, wo shoutd ateo not completely ignoro the taet tint the stomachal conditlons whieh ocension fintulence may at limes appenr to be of consldernble imperinnee, inken wilh other exciting fnctors, in tringing on an attack. Thero may be, as Broadhent points out, a certain sympathetio rolationsilip between tiso terminei filires of the rngi in the stownel and th:0eo In the heart. Mnny tacis weuld servo to domonstmto this possibllity. Certniuly, oven in eares of marked cardine wenkucs, where there has nover been $n$ true angluold attack, lyspeppia of an acute nnd very diatresshg tyjo will frequently follow undue fatigue of any sort or any severo shook to the nerreus systen such as distressing or alnrming nows may readiiy excite.

$\Lambda$ phenomenon wirich is soniowhat curlous is tho fnet of an intenso jesire to urinato during tio period of an altack, oven though tive effort is vain, simply beenuzo the bladder is frequentiy entirely enpty. This statement may not in variabiy bo trie. I linvo known unny a timo cmotiounl excitoment to prevent absolutely for $n$ whilo tho contractio power of the biador being oxerted, anil where, as was provent luter, the bladder containai a conslderahie quantlty of urluc. It requires a very slight degreo of ammoynace or inental tiisturbance in IIen jinst middle ifto to prevent froquently thelr power to void their iriuc. Of course, the contrary of this ls true, especlally among women of a neurotio type, and who aro stiii relatively young. The quality of urino of low apecific genvity passed by thom nt times, lu a very brief incriol, is often very grent. In the differential diaguoels of true nugina with pseudo-angimn, this point shouid bo borno in unidd. During tho allack where it is severo, perapiration will how almost constantly from tho jutient. Ilis face and neek and hands may ho eovored with it. it is coid and olaumy, and lends additional signlfieaneo to tho gravity of the other symptouns. 
The timo during which an nttnck lasts ls very va riable. Somotines it is over after a fow soeonts, although sluring this short periot the agony is fenrful. Again, the attask is prolonged for severnl ainutes. Some nuthord stnte that the attuck nny occasionally last throughont an entire night, and that during all this time the patient lo unable to move at all ou aceonut of the intenso pain, nut, moreover, is perspiring profusely the entiro period. I must confess that $I$ linvo nover seen any attack of this sort, nud nun inclined to consitler then very infrequent.

It is lighly probable, noreever, that in a enso of truo anginn depend. ing "lou mdvaneed degenerntion of the coronary eirenlatlon, whlch woulel probalily be prasent under entel circumstnuces, tho intengo pnin

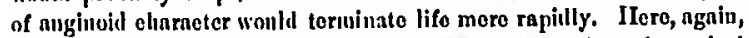
I should lic disposed to hold the view that a nenrasthenlo or lysterienl eleuent wis present, which gave strength anl exactuces to the true lingnosis, viz.: pzendo-nuginn.

It unst be admitted, of conrso, that there aro inslances in which tho attncks are certninly nuginoinl in clinrnetor, nlthough they do not rench their completo dovelopment. 'This fret inny bo explnlued by' sinlling that tho paticut, hnvling sufferen from nttneks proviously, 80 soou as to fnlly npyrecintes thint ono is consing ou simply stops still nutl nvoids nil pessihlo exertion until tho nttnck lins completely jnssel nuay. In theso oxanples tlicro may bo pnin in tho cliest, I wit rithout radintions townrel tho arms or fingers. Of course, if the pnin ls diminlshed ln violence, thero is less drenil ntinclied to tho seizures, nud the jinticit does not oxpect to die nt nay moincut. Brondbent nul others apenk of nuginoil attneks sine dolore. In such instances the chiof dnuger nrises from a syncopnl uttack in which a prelent mny suddonly expire. It may ho that these nttacks lial been originally painful, nut it was only subse. quently that they lost this chameteristic fenture catircly. I shoulil expect, in sted nu instnuce, to find at the nutopsy oither marked fntty degenerntiou of tho henrt walls iudepewient of eoronnry elinnges, or else advisucel aortie royurgitntion. Wherever tho ecronnry eirenlation is sultlenly obstrnetel with an cubolus or thrombus, the brenet pang secins to be alasost an invarial,le aceompnuiment. In those enses whero tho attnek lus eviliently heen brenght on by exposnre or exertien, it tocs not nsunity tast tong, and wtion tho nccidentnt occasion of the attnek has tlisnpyenred, the seizuro itself is apt to dissipnte itself mpidly. Wherever tho attack comes on spontanconsly, as it wero, without nuy necidental effleiont canse being ovident, it is apt to last a longer tinic, and enly to puss awny littlo by little nad slewly. Ocensionally these nttncks aro tho unost nlurning in renlity, and hernid a fatal ternimation in tho net distnut future.

Among tho canses which net effieicatly ln bringing on an attack of augiun aro,primarily oxortiolt. Wo are npt to sny ovor-oxertlon when 
the attack has taken place. This ovor-oxortion may bo a brlsk, rapid walk, or the pationt nay bo walklng Ieisu roly and without effort when the scizun occurs. Usuatty, thowover, it is whon a walk has been pretenget and there is utrendy $a$ foeling of entigue that the minginn is felt. It has been noticed that whenevor exertion takes place soon aftor a meal an at tack is more apt to oceur. It may bo beckuso digcstlon, if soor and torpid, is thus inlerfered will, and gnses which aro genernled aud necumulate in tho stomach press ngalnst tho llinphirnga nad indircetly against the henrt, and thus, by caushng some olisplacement of this orgnn, niny ocension nolablo interferenco with thio circulnlion.

One renson, wo doubt, why attncks occur nt tinics during sleop, is locenuse fatus is prone to acenaulate in the stonneh and lintestines dhring slecp, and considering this together with tho fact that in the horizontal position wo have more pressuro of tho abdomlnal viscern upurard, wo realizo readily couditions which aro porserful in causing distress. Tho liability, under theso cireumstnnces, to nu attnck is incrensed nolably by a feeblo cireulation. Moreover, ns wo kuow, tho circuinlion is alivays icss activo in reploso, and this stato is wint provniis during slecp. A londed rectum is, also, a conilitlon to bo nvolded, and anyono subject to constipatiou numst seo to it that tho bovels aro properly eracunted. Tho distendel bowel may' porhags act ln a reflox mannor, as well as by ilirect pressuro.

Thio infueuco of cold is semetimes very ovidont. This is partleniarly tmo whou a paticut is walking agninst a cold wind. Noliding moro is revuired thail this sousctimes to precipinato nu nttack. On tho other lanud, mijd, waras wentior ls conducive to woll-being, and sufterers frem anglna will often escapo attacks during long porlods when the wenther is freo from rapid clinges and remaint relatively baimy. It is essential at night for a patient to seo that tho bed ls comfortably warm and that ne chilling of the surfaco onsues; othorwise, all attack will often follow. Thals precaution may bo madily nttended to with a hot-water bottle or heated bricks. Gentlo friction of tho surfnes of the body, perhaps, beforo tho patlent retires, is also a proper precaution to takc. Tho wearing of loug woollen stockings, nud particularly those which are somowhat loosely knit and allow free tranguiratlou, is cspecially desirnble, an as to kecp tho oxtremities suitably warm. I know of no small delnil so inporlaut as this lu all affeclions in which lho circulation is notabty impaired, and, of course, it becomes doubty imperative in warding off painful attacks whlich aro toe frequently occesloncd by local chilling of the fect.

In viow of tho fact that dyepepsia ls such a frequent symptom of angian, and appears as an offlcicnt cruse, In the judgmont of a fow "ritcrs, quite as ofton as nu offect, It is Important to avold all late or too abuudant dinucrs. Tho food at thes meal slould bo of tho simplest

TOL 12, xe. 2.-Thenuat, I92. 
kind, nud ne overlendiug of tho stomneh should bo pormitted. In a sinilar wny, uo sauces, condinients, or lasufilclently cookel food should bo tolcratel.

Whenever an attnek loas oceurrel, it behooves the patient to bo more (l,an weunlly eircumenect in all hls doings, not to bring on nnother onc. This la especinlly truo of nuy excrtion whlch seeningly has been the direct enuse of aul outbreak. And yet thls counecl is sonetimes alnuost unnecesenry, becauso tho paticnt's own feebleness, which follows n prinury' nttnek, will compel lilıu nlmost to wnik very slowly ant delih. erntely, oven if lo wnlks ut nll, for somo hours or dnys subsequently. No douit these anginoil attacks would not occur if tho henrt had suftieieut rescric force to respoul neloquately to tho call unde upon it. Unformunety, it lins not, and te ts therefore ovident, in unny linstnues, titat the ntinck is ciircctly oecensioned when we reach final canses, hy tio minifest iunbjlity of tho heart to respond io tho call mado upon it for increased vigor.

Augiun pecloris is not necessarily comnectal with any specinl lesion. P'racticaliy, it is almost nnkuown to bavo clthor stenosis or lncomplo. tence of tho mitral valive aypent as a direct, efficient eause of lt. It is truc, havever, when thero lusvo heen sevcral nttacks of mugina, it is not Infrequent to olservo mitrml Incempeteneo arleo subsepurently. In some of these instmeces it lias lxeen notel, whoro nortio bicenjuctcice already oxistal, that this nffeclion was anolioralad as regards its aj'mptoms, mid thint the miginoid nttacks also became less sovere. Tho explanntion appenrs to be in tho lesseseal blood pressure thus brought aleeut, as aliown in the arterial pulse and in tho dinlouslicd necenluntion of tho nortio second senud. Mhsser' lus insisled upon tho Importanco of this fiuding, and has reportel soveral examples la his orru experience. Jlondluent' has also specially cmplinsized ainillar Instances.

Angina la frogucutly connceled with fibrous inyocarditis, aud at the nutopsy such organlo clingo in tho licart nuuselo is apt to bo found. So usunl is this condition that Gibson stntes it is almost a surpriso not to find it. When florous uyocarditis is noted, it is frequently acconpaniel with ovidences of arterial degoneration. The coronary arteries nre usunlly Inplicated. lespecially is this true where norlitis ls preseut. The lesiou unay be liniterl to their origin, which is eometimes narrowed and thiekenoil. Tho nrteries may nlso be affected in a considorable oxtent, and tho organio elianges many bo considombly advaneed. Ocensioually thoy havo uneroly lost clnstlcity; In moro pronouncel altcrntion thoy inay havo becomo markedly atheromatous, or, ludeed, calcifiel.

Accorling to Deuglas Porrell, fatty legeneration of the heart walls often exists. Sonetinies, indeed, the heart is so mueh degenornted that

- Trenaction of the Amocistlon of Aunertcen Pbydiclans, rol. $x$. p. 85.

Brith Neilical Joimal, 1591, Tol, I. p. T11. Quoled by Oater. 
it la easily torn, and the fingor slnks into It on allght prosure. Somo. times, to the naked eyo, the fat exlsts only in pateice, nffocting meroly the papillary nuscles or different areas of the ventrleles. Lvou in theso instance, however, It wo make uso of tho mleroscopo, wo nro apt to find consillernblo degeneration of thio waliz, where there has been no real change of coloration. In a fow Instances the nileroecope showe almoet conplete dizappearance of the nusecilar fibres.

As n coneurrent condition vith fatty degeneration, we discover moro or Iess aulvnneed einnuges of tho coronary arteries, very simlinr to thoso alrenly inentioned in eonnection with fibrous myoennlitis. Thego cvlienees of intty degeneration aro partieularly found, of enurae, where the fatal termination appears to he Intinately dependent npout the pro. vious neginoid attack. It silould bo rementeel in this pineo that wo often linve both antorlor conditions, viz.: that of fibrous nuyenenditis or of falty degrneration, withoul lisvlug attacke of true angiun. Accord. ing to Gibson, thio rolations of anglua wilh endocardlal lesions ls not so distinct. It is true, of coureo, thint icgenerntion of cardise wrilis may often causc $l t$, and, therefore, it is trequently found at the autopsy. The earlier writers, like Atorgagni, certainly attaclied naginn lirestly to the oxistence of aortlo discrse, nunl In one of Ileberden's enses, whoro the autopoy was mado by John Iluntor, thls affection is duiy recordad. On tho othor hand, wo know that tho moot ndvaneed changes with ossifieatlon may oxist at tho aortlo orifice, and jet there inay bo present during lite no morbid synptoma at all.! Theso inatances

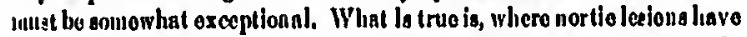
been provon nt nutopsy, often pain lins been notel prlor to dentl. No woulit, this pain hes been lu part duo, at lesst, to Intorference with the cerronary cireulation, causod by aceompanying nortltis, with whlch there any he also a certalu degree of illatation, or, lndeed, $n$ sneculated ancurisa. Artorial degonorntion, capeclally arterlo-ecicrosis, is often aljoined to nttaeks of anglna. Whero tho corennry arteries nre degenerited, antl whero tho angins is seemingly dependent upon thls condition, we should not loso sight of tho tnet that tho other arterles, being ilegeneratel, are also doubtless contrlbutory. Ilie affectlon of tho corounry arterics througlt selerosis and conseqquent narrowness, provents a suffieient blood supply reaching tho heart, and heneo Interferes with its nutrition. A throubus or ctnbolus nany obstruet the vessels, but it is loubleful whet her ono or the other of theso conilitions causcs nugina ((iitsou). One thing is sure, vlz.: we olten find eniclfication of theso arteries without provious anginal attacks. Adberent perienrdium mny be fousd, but does not occrslon nnginal nttacks unless necompanlel hy a lesion at tho nortio orifice. 
Augiun lins been observed following lujuries to the chest walls. In these esses the nerta many linvo lseen affected. Broalbent states its presence occusioually in malarial fever. It many also be present in advancel linbotes where the arteries nuny becomo thlekenel, thus giv. ing rise to incrensed tension, nucl followed by nitncks of truo anginu. It is not infrequent to find ninginoill nttneks ocensioned ovidentty by the presence of the gouty poison. In these cases the prognosis is only scrious where tho intracarlino changes nro alrendy alvouced, ns sloww hy the wenkuess nud irregularity of the heart's pulsalions. III seme of lhese cases wo find 110 abbly fibroill myocarilial clanges in patelies or disseminnted. Fien In these instnnees, prior to denth, there inay linve been fow or no threnlening cardinc symplons. In a fer raro cases neuritis of tho carlino ploxus nuth also of tho plirenie nervo lins been uotel (Inuseerenux, P'cter) whero nngiusil nttneks linvo oceurred. The viow of Semplo lo, indeed, that nuginn eonsidered as aul idliopnthio ilsenso is conucetel whth na alfectlon of the pneumegnstrio or plirento uservo. Of counse, it ls difficult nlways to pronounce rrliat tho preciso strueturnl elinuges nre. Still, thoy nro doubtlass juresenl, and Inler will lio discoverel. Sennwhilo wo nro forcell to rank a few anch instances nmoug the " neurosea." Frequecutly, doublless nngiun is nssocinteal with nilumte structurnl changes whleh ouly sulseguent eleso lusestlgation will determine. Filiut is ovilently of the opinten that the ceunectiou hetween nugina nnd orgnnic lestons of tho hen rt ts rare. 'Thus ho has ouly observel fifteen cases in 388 cases of the latler. Agnin, litint snys thint in ten years lio lins noted ouly four creses of truo nngiun, that ta to say, wlere the dleenso was umeonuected with cardine or nortic lestons. It is clenr that in all instnnees whero there to present an organio lesion of the lienrt or arterics, whatever suffering, if nny, tho patient may expericuco should bo directly oxplainet by them. This Iends to tho conviction that only thoso enses in whioh no encit lesion is illscevornblo slienlly bo rankel among the truc enses of angina. As a rulo, whell sutdlon dentles occur in whint has leen enlled nngina, pathological lesions sufficicntly explanatory are found at the nutopsy.

The condition of tho licart during nn attack of nuginn lins been beliovel to tro eno of apnsin. At lensl, lhis is lise upinion of some writers. It is certainly truo of Ileherden, who first so accuratcly sleseribel threo attacks in his commentaries. This does not ecein to be allogether a tenalie opinjen, If ono hins regard to tho fnet that the lienrt lins rarely been found thus centrneted.

Usmally tho licart stops lo diastole, numl is tonnd nfter death in a relaxed comdition. Agnhu, during lifo, while the pusse at the wrist is sometimes irregular and wenk, it nover disappens entirely, whleh it certninly weuld it the heart wore in $n$ stnto of forelble, spasinolio contraetloll. 
It leas been supposed that tho heart during an attack presented a sort of hour.glass coutrnetion not dlesimllar to than of the itorug. Thls may bo, and yet lt would bo difficult to provo. Bronulbout cenfeases In this councetion that ho has a very inperfect notlou of what tho condl. tion of tho heart really is during an attack. The ovident fact is that luring a paroxyen of angina stress is put ujoen the licart to whleh it is quito unequnal to respoad, nal thus if shows Its cousidorablo lack of power. Often tho stress put upon the henrt is duo to tho continuous high tenslow of tho peripheral ortorles. Occnslonally, howover, thero is lorr teusion in the poriphlieral circulation, numl In theso lustances, if there ocenr a sudden geueral arterial spasm, the anount of work thrown upon the leurt becoates rapldly nucl grealor, and onmeequently thio heart shoirs relativoly greater distres than where tho periphlernl resistanco is esuthuously high and oxaggerater. In thoso eases whero thero is warked nail cuntinuous high tensloa in tho poripheral arterles wo might supposo tlint pain lu augiun was oxplalued by grenler pressuro throwin upout the lieart. Thls can seareely bo truo when wo cousililer

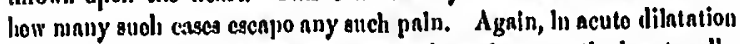
of tho ventrioles, wo liavo great presenro bronght upow tho lieart walls, and yet no palu results. Nouralglo predisposition le ocenelonally given as nil oxplanatery cnuse. This is senreoly true if wo menu by that aul neepuired or opldent ucurotio teadenoj, since thls disenso occurs moro freipently witl wes than wlth woinea. It would acen as though from tho fact that when tho nttnck occurs immediately, tho paticnt stops doing muything lo is occupied with, or oxcreising, if that bo what ho is about, that thero is a certaht pro-orderell protectivo arrangeuecut luternally" to gunrd agninst theso outwarl annuifestations of man's lifo. (IIroml. beitt.)

''nin, necording to Brauswell,' is duo to irritntlon of the nervo teruimations in tho walls of the heart liself. Ho nilinits, howover, that the thicory of Irritation dne to spnsmodio contraction is planslble, nud compares this opinion with what oscurs ln the calf nuscles, spasmosirally cont racted, in ordinary crmmp.

Attacks of false anginn often resemble those of tho rent kint. Sometimes tho elescription of the attack by friends will cuablo us to renel n correct dinguosis. If tho patient beconics palo, nuxlous, nnt shows sigus of grcat distress, It may not of necesity bo truo nngiun. It, ou the contrary, thoro bo no such clianges ovident, wo can bo very suro that it is oully nu attack of psoudo-angina. Thero is mucl unreliabllity in tho patient's aceounts, malnly becauso they aro aph to rend up plout these nttncks, aull often glvo an exaggerated iden of thelr own seliantions. Ago will throw souno IIglit upon tho dingnosis. Under forty 
ycars of ngo In tho inale, auglna occurs very rarely unless there bo a pronounced icsion at tho aortio orifice or aortitis. In females it is rare at any ngc, although attacks of pacudo-anglna aro not Intrequent with them, especinlly thooso of nul undoubled nourotio temperanont. IIelerden, tor exauplo, In spenking of tho esses observed by hilin, being la numbor orer 100, stales that three oceurred In woinen, 0110 in a boy, twelvo years of ngo, and the others in men near or orer fifty years.

Usunlly the finst attncks of anglua oceur luring phykleal oxertion. Lator on they many come on sovorely nud more readily, and then we may unake the dingiosls surely, oven theugh tho delermlulug cause is slight. Tho physlcal oxamination will revenl, in case of true angina, the changes montlonel in tho nerta or at aertio orifice. Whero tho attack at firat concs on without exertion and at a fixel period after Ingestion of fool, It would scom to be of digeslivo provenanco or peectulo-angina, and ordinarily lue to a dyspeptio attaek. Unless history, nature, anll noset of nttack all concur together with phynical algns to cstablish diag. uosis of true angiun, we should lan atrongly to dingnosis of peeudn. anglna, null nlinest Invarlnbly, If we can discover any fnets to aujport this diagnosis. If wo lenve out nttacks of peevilo-angina whlch are ovidently nourotio or of hysterical nature, ne can usually find lu sonse digestivo ilsoriler, partlenlnrly of tho stomach, a suffieient oxplanatiout of theal. Thiere aro ometntion, narked fiatulence, pain, occasional altacks of Inuses or vomiting, whleh all point. in this illreetlon. A coniblnntion sometimes fountl is thint of dilatation of the stonnch, with lighl nrterial tension. It tho heart bo affected in theso cases nud they neo lusproporly trentel, a tatal result inay not infrequently toliow. If, for oxnulplo, digitalis or nltroglycerin bo alono used, or the Bchott Irentment advisel and cnrricl out without nuy care of the stomnch, aull especinliy If the subject ho old, suelt a denotionont may not bo " surjuriso.

'Tho proguosis of truo angina is often ancortaln; and yet wo lase certain conclitions which guido us 10 mako it correct. Wo shoull catimato carcfully the rulative predonnlunnce of tho two factors ofter proilucing It $\rightarrow$ on tho ono linul, degenorated lieart walle, on tho other, vaseular cinnuges. If thero bo high arterinl teusion preaent, nuid it at the eamo tlino tho heart action is foreible anul the aortlo sceond eount markel, wo inay hope lyy proper treatment to modlly theso condlitions for a while with tho use especinlly of nltreglycerlu and tho nltrites. Agail, if avor-oxortlou and oxcitcuent brlug on the attacks, or If Inntuiont ijspepsia be a decilecl and powarful influenco in produclng thew, we should liope to nvoll with care and trestment their nalural outcome.

On no account should tho patient walk hurricelly, cspeclally lu goisy (1) hill. IIo sliould nlso nover tako oven a moderato walk untll a eortalu thoo leacl elapsel after hlo last repest. 
Attacks of anginn whlch accompany nortio disenso may last a considerahlo time wlthout bringing on a fatal result if earofully watehed and guarded. Tho worst eases a ro theso which recur in tho night or at times whoro no aceidontnl ealse ls present and avoidablo whleh oecnsions then. Again, if oxamination is relativoly negativo, if tho heart is of normal sizo, without manifest lesion of nny kind, and yet its action is fccblo, its impuleo scarcely folt, nnd tho pulso usunlly, if not invarially, of low tenslon, theso give great anxiety by reason of tho vaguences and uncortalnty as to tho conditions whleh may bo present and at any timo becouno imminontly tirrentening.

The apparent soverity of two attacks may bo similar, and yet tho relativo dangor of thom may bo nbsolutoly difforent. It is diffleult, thereforo, nt timcs to make miything liko a suro foreeast. Of course, whero thoro aro pronounced earliae med artorial ehanges, and whero, fil addition henrt fnilure lias followed hypertroply, the outlook is assuretly very gravo indecl. If, at the sanio timo, aortio regurgitntion also bo present the progisosis becomes oven moro sorious, In a similar wny, if elironio renal changes exist tho future of the patient must aipenr dark and immlnent. Gibson states that the proguogis of thoso affected with fatty degonerntion is far less serlous than tho preceding. l'rovided nlways the oxternal nud aroldablo enuses of aggrivation aro prevented, sueh patients may often livo many years. Of courso, toxio angina is far loss gravo. As a rulo, with tho removal of tho canso the enso becomes curmblo. In ucurotio eases, whilo wo ehould oxpect fre. quent recurrences of tho parexysins, it is whelly imprebable to lave a fatal ternilnatiou.

In this category may be placed frequently tho so-called iliopathio casce. Thoy are often oxtrenely painful, but ay no incurnblo lesions exist, they toud to improvement or recovory if properly mannged. Of courac, wo should bo eareful in making oven in theso enses too favornblo a prognosis, since thero nasy ho somo undorlying struetural change of the heart walls or coromary arteries which, during llfo, could not bo leterunined. There aro unquestionnbly, necording to Bemple, certain easez of puro angiua in which tho nutopsy revenls no organlo ehanges.

Tho treatment of angina dopends upon what is tho apparent or ohrious causc. In many instruces, owing to tho difficulty of trmeing accurntely to what tho attack is primarily due, our treatment mumb be essentially empirieal. First of nll, wo must consider tho general health, anl from this point of viow our treatment should bo hygionlo. The means at our command aro hero what pertain to nir and light, rest and exerciso, food and drink. Aftor these hnvo all been inquired into nnd reguinted, as far as may bo, wo naturnlly seck for the prejer medicinal remedies to moet the indleations of each epreelal case. In genernl, nlso, the efficacy of our treatment will depend much to what degreo wo lingy 
to ublo to roliove porlplicral resistanes to a henrt frequently veakencel. If, jerchnice, wo flul between the regular pulse beats, ovidence of ilerensel tension to nur tnetilo senentions, wo may offen reduce this by npprraptrinto remcelics. Still, in orler to recognize it, wo must at times oxamluo the liestrt aut arteries nt different perlods, boloro and after oxertlail. Nol iulrepuenily tho arteries aro nolably degeneraled, harl, thickenol, tortuous, ansl oren entenreous. Wo can ben do linte lis nffect them directly. Yet, the capillary ajaten, in which thero may bo nolnhle resislance without oxcesivo chnnge, nut whlch lins cnused iu "tuensuro tho arterial and cardiac chamges, any bo stlll favorably influcucel by approprinto druge, and account should be kept of this fact. II gonty contitions the periplic ral circulation may slow in ereasenl tonnium, nithough nol vlsilily tlegonemied, aud uhls condillon, of course, uny bo firomily lutluenced ly approprinle meelieation.

II these latter enses tho orlinary treat ment with a nereurial, fol. lowed ly, in salinc, once or twice n reek, will lower arterial preasure. llat ween times tho 1130 for a vililo contianously of iodiulo of potash ani nolchletuin Inay loo of sigunl beuefil. Tho employmeat of hitter tonles, if the Inulicution presents, and the proper regulation of the diet is of cunne usoftul Xecrorling to l'uxell, hoj, colinmlsa, and eltiretta are lietter toul's in theso cases than inulnino anil sirychuino. In tho" neu. rulgio houts," to wilich they uro prone, he praises quinine and phen. netiu. W'licro anginn ıceurs with tuarket nortic ulisease it is difficult soinctimes to know to whant extent we may be alslo to help the attack a loy reilucing tensiou uf the pulse. Whicre the pulse remalns feeble hot weven tho nttacks, wnit tho henrt has n wenk liujulse, we shonlli care. fully culcavor to help with carlias tomica, lut freynently wo call be of litele real xervico th viow of the promouncel iegenerntivo changex present in the heart unl urteries. Oecrsiovaliy anenic, conbinel witl

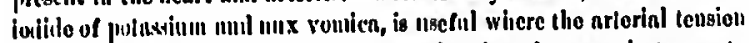
is nut tou promunncel. I'reference may bo given in many Insiances to the solitim sult of the ionlide, both between and sluring the attacks. decurling lu Secholl, it is les prone 10 cnuse hent foilure; but creu this satt is " upt to destruy tho uolecules of albumin" if conthmed ton long or in increusing lases. Milk is the best menstruun for cither sult, ns in this way stounucluml intoler'ulce is less likely to occur. In these ancl ather eas's wo should try to preserve tho use of tho nitrites: null nitroggyerriu for tlio uttucks. Formorly the tliffusiblo atimuinats, iiko bnumly, unumouiu, lavemiler, cauphor, ete, wero much usel for tlices nttacks. Now they aro alanost almamlenel tor nitroglycerin and nitrite of muyl. Theso Intter aro particularly useful in relicving pain, nInl to necumplish it thoy dilato peripheral arteries. Nitrito of amyl ly the rapitility of its uetion is preforubly entployed. Nitroglycorin IIII the swicot spirits of nitro produce sinilar effects la different ilegrees. 
All of these nro free from dangerous effects, ns a rulo: not co of nltrito of sodium, whicb may produco alarmlng results (Glbson). Nitrlto of auyl and nltroglycerin dllato arterles, increnso frequency of pulso and respirntion, and reduco Irritabllity of tho nervous system. Wliero imcreased neceloration of tho pulso and resplration aro alrealy present the vilriles must bo oniployed will great care, as thoy might possibly causo grealer distrese. While they are enid to be henrt slimulauls, they uainly eauso relaxation of tho arlerles and also of tho cardiao musecular filıres (Ilroalbonl).'

Tho nitrites havo thoir elrablucke nlso in tho fact thent patients find so much relief from tholr uso that they uso then too frequently nut injulicionsly. A word of waralug should bo thrown ont becauso lifo is sometimes shorleneil by their inconsidernto ueo. Glycosurla has been produced by them, It ls stated. In many juatances tlio nltrites aro legs useful tlinn jodldo of potaslı. Nitrlte of amyl may be earried about with ono so as to bo used lannediately. Tho nitrito of amyl ln glags glolutuleg, of 3 to 6 nilulms, may bo $\ln$ a sllk bag nut broken upou n lastelkerchlef and inlınled as requlred. Tho nitroglyeerin tablete, ono one-hind reth of a graili, may also bo taken ln doses of ono or two when attack oceurs. Thoy do not act as rapldly as tho nitrito of anyl, bitt their effeet la moro prolouged, and on that account may bo more valualsle in certaln casce.

Somo enses, lowovor, aro not roliovel by nitroglycerin talilets amel aro nelicvel by nltrito of amyl. According to Bronibent, suclo enes lavo sesned to lilas to origiunto lit tho rlght ventrlelo.

It is tho belicf of Dr. B. Addy tlint wo hnvo in erytlirel tetranitrato a remedy superior ovon to " nitmglycerin," its effects being very rapid and inoro lasting. Tablets of one-half grain each wero given lyy liun twico or threo times a dny. Thoy did not cause headneles, and tho remoly soow checkod tho attacks. It is true, tho patlent died after a forluight of syncepe, but during this period grent relicf from suffering wiss exporicneed.

Sometimes, where the henrt is werk nud tho nitrites do net relicve, althongh thoy may relax tho poripheral eirculation, wo must recur to the old slimulants. In aldition, a turpentiuo slupo, or mustard lenf, or fHultico may bo applied ovor tho chest and will oecnsionally afford a inenguro of coinfort. Whenover theso local applicatlons fail, grent relief is olstained from a hot-wnter bag at $n$ temperature of $140^{\circ} \mathrm{F}$. to $170^{2} \mathrm{~F}$., "noved witl light louclics over tho wholo eliest."' If, despito all this, tho attack is prolonged and nureliovol, wo must givo a lypalermic injection of morpline and atropluc, using at first small

- Thls optalon aboul beart fbres I do not bare ave rery exceptlonally.

" Mrlltsh Jodical Joumal, May 6, 1899, p. 1089. 
doses, and later, If need be, beconing bolder, and using lnrger doses. It ls well to make lujeetions deep in tho muscle, whero tho eirenlation ls moro activo than in tho cellular tisme under tho skin. In sono listances, wo sliould rceur to chloroform lulualations as belug tho ouly loojw of relief to tho patient. At times thoy are undoubt. cally dangerous, and especially is this believed to be truo if fatty lieart ls jregent. As a matter of faet, however, fatty lieart cannot always he dinguosel with aceuraoy. Tho apex may bo strong and tho fullso regular nut gool, and yet fatty henrt may oxist, mul sadden dentli follow. Agaiu, morever, it has becn sliown that chloroform may ho given safoly whero fatty lieart lator is known to oxlat by the rovelntions of the nutopsy. Wo must reliove intense pmin, lowover, oven if thoro be risk, and it con onty ho dono at tinies toy guets agents (Ilulfour).

In cases whero thero is marked henrt fniluro, ether or brandy should

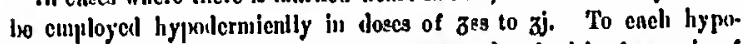
leraio injection one or two tablots of one ono-hundredth of a grain of ultroglyeeriu miny bo ndled. 'The Intter should bo employed witlt enutlou, howovor, as occnsionalty consliterablo soreness and even uleern. tlou of tlio skiı may result.

'Tteodoro Bchott dow not vatuo very higtity digitalis or slroptinnthus if enges where tho heart requlres stimulntlon, oven in uncomplieated forms of nugiua pectorls enuscl by gelerosls of tho coronary vesecls.

Oxygen iulialntions aro often niso useful, not only to satiafy the air liunger, eluo to obstruction of elrculation in tho lunge, but also to sliuulalo cardino circulation and help untrition of its musclo, and thus got ricl of effeto innterial whlch intorferes with proper metnbolisn (l'awcll). In theso crises tho oxygen must bo used with a fuunel near the noso uud unoutl, so that it uny be Inlialed frequently anil without offort. As corroliorativo of tho oxtreme valuo of inlaalations of oxygen li tho treatiment of somo severe cases of angina peetoris, I would refer to ono recently roported in tho Brilish Medical Journal for Decenber 1, $1000,11.15 \mathrm{tg}$.

last in hed for a timo is often desirnble nfter neito paroxysns have passed, but later it is uscful, as far as possible, to get tho patient hack to hly orliunry lifo with judicious restrietions. The eame rules npply bere, howover, ns in other henrt affections. Wo must remeniber, also, that oxcrtion whlelı oue day may scen nll right, nnother day may eause itist ress and opteresion. 'This is ono of tho objections to Oertet's systen of treatment (Broadbent).

l'hysienl therntly is midubtedly usoful in somo iustances, but it unst be utilized with grent care. This counsel pertains particularly at thu present timo to tho trentmeut as instltuted at Bad Nauheim, wher: tho resistant movoments in conjunction with carbonio baths aro prac. 
tised. In advancel nrtorio-sclerosls overy in erenes of tho blood pressure which is tho resuit of this trentment might lead to fatni coneo. (tuences (ombollsm, npoplexy, rupturo of nnemrism of heart, or norta). "Advauced seierosis is, theroforo, n contraindication for thils trentment" (Bchott). Tho vuluo of many nedieaments in angha comes from produeiug low blood pressuro. Tho balneologleal and gymuastio treatilent exereises a tonlo influenec, nnd " by strongtlioning henrt illuscle, ns woll ns by acting on eardiao nerves, distresging symptoms of nuginn aro either reinoved or reduedl " (Schott).

Guidanee shouid bo had in regnrd to tho bnd effeets of winds, great hent or cold, or rapld ohanges. Also, nu atmoeplicro heavily lalen with moiaturo la Injurious. Internal conditlons of dyspopsin nnd constipation must bo warded agninst. $\Lambda$ great denl of taet nnd good judgment aro required, aud tho patient's disjositiou should be thoroughly kuown. Rest, partlcularly aftor monls, should lo lislsted upon, as patients ire particulnrly liablo to at tacks nt theso tlmes.

In general, supervision and counsel must be employed about exerelse. II'lero nn nttnek lins latoig oceurred, it is wislom lo refrain from exertion for a while, especinlly if tho heart is weak and fluttering, nuil afforl it thino to ro.esiabliais itself.

\title{
THE PATHOLOOY OF TIIE IIEALFD FIBROUB ADHIBIONB OF TIIF PIBRICARDIUA.
}

\author{
Hy II. Gineos WRLLI., MI.D., \\ aSSOCIATE IN PATHOLOOY, UKITERBITY or CBICAGO.
}

Is $\mathrm{n}$ totni of 1048 antopisics upon tho bodies of nduits, tho recorls of which are nmong thoso of tho Pntlological Laborntory of Ruglı Medical Coilego (in nffilintiou with tho University of Chlengo) and of tho Cook County IIospitnl, somo inflaminntory cliango wns found in tho porienrdium In 128. Theso ehanges included ovorything in tho nature of a perienrditis, from tho frmuk seroftbrinous and tuberculous proceses to thoso with but a thin fias of fibrin over a small amen, or a fibrous land unitlng tho pnrietal and visceral lnyers nt somo point. Of theso 128 enses 57 showed ehanges that wero essontially olironio, tho lesion consisting of fibrous tissuo unitiug tho opposed surfaees for a grenter or less extent. Theso figures agreo elosely with thoso of Ieitdet,' who found in 1003 nutopsies ndhorent fibrous perieardltis 01 tines. Tho remaining 71 were aeute, and represented all tho eonditlons usually scen in aeute perieardltis.

Of tho 57 cases with fibrous adheslons tho cause could bo at tributed to rieunatiom in 8; in 8 the lesion was frankly tuborcuious, as shown 